\title{
SOIL AND NUTRIENT LOSSES IN EROSION GULLIES AT DIFFERENT DEGREES OF RESTORATION ${ }^{(1)}$
}

\author{
Roriz Luciano Machado ${ }^{(2)}$, Alexander Silva de Resende ${ }^{(3)}$, Eduardo Francia \\ Carneiro Campello ${ }^{(3)}$, José Arimathéa Oliveira ${ }^{(4)}$ \& Avílio Antônio Franco ${ }^{(3)}$
}

\begin{abstract}
SUMMARY
The most advanced stage of water erosion, the gully, represents severe problems in different contexts, both in rural and urban environments. In the search for a stabilization of the process in a viable manner it is of utmost importance to assess the efficiency of evaluation methodologies. For this purpose, the efficiency of low-cost conservation practices were tested for the reduction of soil and nutrient losses caused by erosion from gullies in Pinheiral, state of Rio de Janeiro. The following areas were studied: gully recovered by means of physical and biological strategies; gullies in recovering stage, by means of physical strategies only, and gullies under no restoration treatment. During the summer of 2005/2006, the following data sets were collected for this study: soil classification of each of the eroded gully areas; planimetric and altimetric survey; determination of rain erosivity indexes; determination of amount of soil sediment; sediment grain size characteristics; natural amounts of nutrients $\mathrm{Ca}, \mathrm{Mg}, \mathrm{K}$ and $\mathrm{P}$, as well as total $\mathrm{C}$ and $\mathrm{N}$ concentrations. The results for the three first measurements were 52.5, 20.5, and 29.0 Mg in the sediments from the gully without intervention, and of 1.0, 1.7 and $1.8 \mathrm{Mg}$ from the gully with physical interventions, indicating an average reduction of $95 \%$. The fully recovered gully produced no sediment during the period. The data of total nutrient loss from the three gullies under investigation showed reductions of $98 \%$ for the recovering gully, and $99 \%$ for the fully recovered one. As for the loss of nutrients, the data indicate a nutrient loss of $1,811 \mathrm{~kg}$ from for the non-treated gully. The use of physical and biological interventions made it possible
\end{abstract}

(1) Part of the first author's Master Thesis at the Agronomy-Soil Science Post Graduation Course, Federal Rural University of Rio de Janeiro - UFRRJ. Received for publication in May 2008 and approved in February 2010.

${ }^{(2)}$ Doctorate course in progress in Agronomy, Soil Science, at UFRRJ. Scholarship from CAPES (2007 and 2008). Professor at Federal Institute of Education, Science and Technology of Goiano, Morrinhos. BR 153, Km 633, Zip Code 75650-000, Morrinhos (GO), Brazil. E-mail: rorizmachado@ifgoiano.edu.br

(3) Embrapa Agrobiology Researcher. BR 465, Km 7, Zip Code 23890-000, Seropédica (RJ). E-mails: alex@cnpab.embrapa.br; campello@cnpab.embrapa.br; avilio@cnpab.embrapa.br

(4) Professor at Rio de Janeiro Federal Institute of Education, Science and Technology - Nilo Peçanha Campus - Pinheiral (former CANP/UFF), José Breves St - Centro. Zip Code 27197-000, Pinheiral (RJ). E-mail: aricanp@vm.uff.br 
to reduce overall nutrient loss by more than $96 \%$, over the entire rainy season, as compared to the non-treated gully. Results show that the methods used were effective in reducing soil and nutrient losses from gullies.

Index terms: Valley of Mid-Paraíba do Sul River; water erosion; leguminous trees.

\title{
RESUMO: PERDA DE SOLO E NUTRIENTES EM VOCOOROCAS COM DIFERENTES NÍVEIS DE RECUPERAÇÃO
}

\begin{abstract}
A forma mais avançada da erosão hídrica, a voçoroca, constitui um sério problema de diferentes contextos nos meios rural e urbano e, para a busca da estabilização do processo de forma mais viável, é necessário avaliar a eficiência de métodos acessíveis. Nesse sentido, este trabalho objetivou avaliar a eficiência de práticas conservacionistas de baixo custo na redução da perda de solo e nutrientes em erosão por voçorocas no município de Pinheiral, RJ. As áreas estudadas foram: voçoroca recuperada, com estratégias físicas e biológicas; em recuperação, com estratégias físicas; e sem intervenção. Foram realizados: classificação do solo das áreas; levantamento planialtimétrico; determinação da erosividade das chuvas; quantificação dos sedimentos, sua granulometria, e teores dos nutrientes $\mathrm{Ca}, \mathrm{Mg}, \mathrm{K}$ e P pseudototais e $\mathrm{C}$ e $\mathrm{N}$ totais, referentes ao verão de 2005/2006. Nas três primeiras avaliações, foram quantificados 52,5, 20,5 e 29,0 Mg de sedimentos na voçoroca sem intervenção e 1,0, 1,7 e 1,8 Mg na voçoroca com intervenções físicas, o que significou redução média de $95 \%$. Na voçoroca recuperada, não houve produção de sedimentos no período. Considerando a perda total nas três voçorocas, a redução foi de $98 \%$ na voçoroca em recuperação e $99 \%$ na voçoroca recuperada. Em relação à perda dos nutrientes na voçoroca sem intervenção, foram quantificados $1.811 \mathrm{~kg}$. Com as medidas físicas e biológicas de controle, foi possivel reduzir as perdas em mais de $96 \% \mathrm{em}$ relação à voçoroca sem intervenção, considerando todo o período chuvoso. Os resultados mostram que o método utilizado foi eficiente na redução da perda de solo e nutrientes em voçorocas, nas condições do estudo.
\end{abstract}

Termos de indexação: Médio Vale do rio Paraíba do Sul, erosão hídrica, leguminosas arbóreas.

\section{INTRODUCTION}

In the last decades, the primary research focus in water erosion was mainly erosion from interrills (either laminar or superficial), as well as along rills, for which experimental lots were used (Valentin et al., 2005) for the determination of soil loss rates linked to surface runoff under different climate conditions as well as soil practices, using empiric models (Poesen et al., 2003).

The study of gully erosion has to date been neglected due to the difficulties of investigation and of prediction (Valentim et al., 2005). Nevertheless, in recent years, this erosion form has attracted increasing interest in erosion studies, as seen in the last international conferences held in Leuvem, Belgium, in 2000; Chengdu, China, in 2002; Mississipi, USA, in 2004, and Pamplona, Spain, in 2007 (UPNA, 2009).

Santos et al. (2002) stated that gully formation begins with interrill erosion (laminar or superficial), followed by concentrated runoff, thus initiating rill formation, which further evolves into gullies as a result of the increase in dimensions of the channel. Gullies can also be formed by surface runoff, by the concentrated flow that caves tunnels called piping, which is responsible for great internal sediment removal and can lead to landslides of the overlying material (Guerra, 2003).

According to the international literature, gullies can be classified as ephemeral, permanent or classical, and also as bank gullies. Permanent gullies in agricultural areas are defined as channels with dimensions that cannot be easily corrected by means of simple implements in cultivation, and which can be from 0.5 to more than $30 \mathrm{~m}$ deep (Soil Science Society of America, 2001). Foster (1986), cited by Poesen et al. (2003), stated that in 1980 the term ephemeral gully erosion was introduced aiming to include erosion in concentrated runoff at a greater scale than from gullies in rills, but less than from classical gullies. There is a longstanding concern about the importance of this kind of erosion as sediment source, although ignored so far in traditional assessments of water erosion. Bank gullies are channels formed as a consequence of the height of the water fall, resulting from the different level of the drainage area and the terrace or water stream, in places of erodible banks (Vandekerckhove et al., 2000). 
As a consequence, gullies lead to a reduction in soil fertility, loss of areas, increase in production costs, sedimentation and contamination of water bodies, etc. (Poesen et al., 2003; Bertol et al., 2004). According to Valentin et al. (2005), the formation of gullies is related to steepness, soil crusting (compression), capture area (drainage), lithology, piping, intense rainfall, changes in the soil management, road building, history of use, climate changes, etc.

In relation to prevention as well as control actions, literature lists practices of soil conservation, minimum tillage, soil decompression (Poesen et al., 2003), runoff deviation by terraces, dams, grass planting, land fills, temporary and permanent barriers (Soil Conservation Service, 1973), and re-planting of leguminous species inoculated with microorganisms (Macedo et al., 1998).

Among the areas with the most severe erosion problems in the southeastern region is the basin of the Paraíba do Sul river, mainly in the area of the mid-valley of the river. The history of occupation began with the Coffee Cycle in the $19^{\text {th }}$ century, followed by pasture for extensive livestock production, using fire rather than adequate management techniques, together with the strongly hilly topography, known as "Sea of Hills" (Ab' Saber, 1970), altogether resulting in severe soil degradation, with a currently great incidence of rills and gullies (Dias, 1999, cited by Dias et al., 2001). These erosive occurrences in the region are seen as one of the main causes for the sedimentation of the Paraíba do Sul River, the main water supply for more than 9 million people in the metropolitan area and city of Rio de Janeiro (CEIVAP, 2002).

According to Poesen et al. (2003), there are a number of questions concerning gully control, such as: when should prevention and control actions be implanted? What tolerance level should be allowed for soil loss caused by gullies? What can be learned from successfully treated as well as from the failed recovery of gullies? How efficient are control actions?

In this context, the current paper had the purpose of characterizing relief, soil and rainfall, and therefore evaluating the efficiency of low-cost conservation practices aiming at the control of soil and nutrient losses from gullies in Pinheiral, RJ.

\section{MATERIAL AND METHODS}

\section{Study area}

The experiment was carried out in Pinheiral, state of Rio de Janeiro, a town located in the mid-valley of the river Paraíba do Sul, between Volta Redonda and Barra do Piraí, in the south of the state (latitudes $22^{\circ} 29^{\prime} 03$ " to $22^{\circ} 35$ ' 27 ", longitudes $43^{\circ} 54^{\prime} 49$ " to $44^{\circ} 04^{\prime} 05$ ", average height of $420 \mathrm{~m}$ asl) (Oliveira, 1998).
This region is part of the characteristic formation of the group Paraíba do Sul, with rocks of different grades of metamorphism, with predominance of granitic gneiss. According to Menezes et al. (2000), the relief in the region is characterized by a sequence of round tip rolling hills called "Sea of Hills", featuring heights between 360 and $720 \mathrm{~m}$, a type Cwa climate, according to Köppen's classification, with an average rainfall of 1,300 to $1,500 \mathrm{~mm}_{\text {year-1. }}$.

\section{Areas of study and erosion control practices performed}

Three classical gully areas were studied using different practices of erosion control: (a) gully recovered by means of physical practices (narrow based terraces with infiltration basins at the edges and bamboo and tire palisades erected in the bed as well as in the surroundings, for sediment retention), and biological barriers (planting of nodulated and mycorrhizal leguminous trees); (b) gully under recovery by means of physical practices (as above); (c) gully under no kind of intervention.

In the surveyed gullies, strategies were implanted in 2000 using three terraces spaced $14 \mathrm{~m}$ apart, complemented by infiltration basins along their edges. In relation to the biological practices, leguminous Acacia auriculiformes, A. angustissima, A. mangium, Albizia lebbek, Enterolobium contortisiliquum, Mimosa caesalpinifolia, M. Bimucronata and Pasudosamanea guachapete were planted in $2 \times 2 \mathrm{~m}$ spacing, all inoculated by arbuscular mycorrhizal fungi as well as nitrogen-fixing bacteria, selected at Embrapa Agrobiologia.

At the recovering gully, actions were initiated in November 2004, by fencing and clearing, so as to avoid grazing and fire. To determine the spacing of the terraces, the slope was taken into account, as well as soil texture and type of terrace, resulting in $14 \mathrm{~m}$ between each terrace, with a total of five units in the area above the gully, located at a height difference of $0.5 \%$, using A-frame level. Thereafter, the terraces were trenched by hand (width $0.4 \mathrm{~m}$, depth $0.6 \mathrm{~m}$, length $30 \mathrm{~m}$ ).

Infiltration basins were built at the edges of each terrace (between 5 and $8 \mathrm{~m}^{-3}$ each), with up to 10 basins, sized according to the surface water runoff, as prescribed by the Rational Method. Although more adequate methods to determine the surface runoff (e.g., method of the curve number) were not used, only a few rain falls per year (an average of 2-3) filled the infiltration basins until overflowing.

With the palisades, a total of ten barriers were built on the gully bed, and three others around it, in places with more developed rills or ephemeral gullies. For this purpose, low-cost, easily available material was used, such as bamboo, old tires and raffia bags. In the interior of the gully, the palisades (a total of eight of bamboo and two of used tires) were built at heights varying from 1.0 to $1.5 \mathrm{~m}$, at an average 
distance of $5 \mathrm{~m}$ away from each other. In the surroundings, palisades were about $1 \mathrm{~m}$ high, at variable distances.

\section{Relief, soils and rainfall}

To evaluate the slope relief as well as the characteristics of the gullies under study, a planialtimetric research was performed by means of the topographic equipment Total Station. The collection area of the slope, declivity, depth, as well as area and volume of the gullies were assessed. The recovering and untreated gullies were investigated, but not the recovered gully, because of the difficulties of operating the equipment amidst the implanted vegetation.

The soils in the gully areas were classified by the Brazilian Soil Classification System, according to Embrapa (2006). For soil sampling, a trench about $1 \mathrm{~m}$ deep was opened in the mid-third of each slope, for the identification and measurement of the pedogenetic horizons aiming at the morphological description of the profile, according to Santos et al. (2005).

With the purpose of relating the rainfall to the sediment production, pluviographic data from the CANP-UFF weather station in Pinheiral-RJ were collected between March 2003 and August 2006. Based on the collected data, both the annual precipitation and the rain erosivity index were calculated, as well as the $\mathrm{EI}_{30}\left(\mathrm{MJ} \mathrm{mm} \mathrm{ha} \mathrm{m}^{-1} \mathrm{~h}^{-1}\right)$, using CHUVEROS software, created by Cogo et al. (2003). The $\mathrm{EI}_{30}$ was calculated for the period from 11/25/2005 to 2/25/2006, by adding up the rain erosivity indexes recorded between each of the four soil loss evaluations.

\section{Sediment collectors and quantification}

To assess the nutrient loss contained in the sediments, collection tanks were built at the outflow of the gully, and sediments from the relevant pluviometric events were quantified. For the recovered gully, a $12 \mathrm{~m}^{3}$ collector, divided into three brick compartments, was built at the beginning of the experiment. For the recovering gully three collecting tanks were dug out from the soil, and a brick drainer in series installed, with the following respective holding capacity: $2,2.8$ and $5.8 \mathrm{~m}^{3}$, adding up to $10.6 \mathrm{~m}^{3}$. For the untreated gully, where a high production of sediments was expected in advance, a $75.2 \mathrm{~m}^{3}$ sedimentation tank $30 \mathrm{~m}$ below the drainage using a backhoe.

The sediments from both the recovering and the non-treated gullies were evaluated three times in the period from $11 / 25 / 2005$ to $2 / 1 / 2006$, plus a fourth time, in 2/25/2006 (when the recovering gully was not assessed due to the breaking of a palisade). The sediments from the recovered gully were not quantifiable, up to the third evaluation (2/2/2006).

The sediment volume was determined by introducing graduated rulers into the collectors. In each collector, the height was measured at every $0.5 \mathrm{~m}$, in a grid shape. Based on these values, the average height of the deposited sediment was calculated and afterwards the accumulated volume in each collector. After volume measurement, sediment samples were collected for soil density analysis by means of a volumetric ring, both for granulometric and pseudototal (total extraction without use of fluoric acid) nutrient analysis. The samples were extracted at depth intervals of $10 \mathrm{~cm}$ because of the thickness of the deposited layer, with three replications. The soil loss $(\mathrm{Mg})$ was calculated based on the mass density data.

\section{Sediment physical and chemical characterization}

To determine the amount of lost nutrients, the respective contents found in the sediments were multiplied by the accumulated sediment mass in each evaluation.

Table 1. Summary of analyses, methodologies and equipment used for the characterization of gully sediments

\begin{tabular}{|c|c|c|}
\hline Analysis & Method & Equipment \\
\hline Soil density & Volumetric Ring (Embrapa, 1997) & Volumetric Ring $\left(100 \mathrm{~cm}^{-3}\right)$, stove, etc \\
\hline Granulometry (sun dried fine soil) & Pippet Method (Day, 1965) & Pippets, screens, stirrer, etc \\
\hline $\begin{array}{l}\text { Pseudo-total } \\
\text { extraction: } \mathrm{Ca}, \mathrm{Mg}, \mathrm{P} \text { and } \mathrm{K}\end{array}$ & $\begin{array}{l}\text { Aqua Regia (McGrath \& } \\
\text { Cunliffe, 1985; adapted by } \\
\text { Fadigas et al., 2002) }\end{array}$ & $\begin{array}{l}\text { Fume chamber, digestor Block, test } \\
\text { tubes, } \mathrm{HCl} \text { and filters, etc }\end{array}$ \\
\hline Quantification of $\mathrm{Ca}$ and $\mathrm{Mg}$ & $\begin{array}{l}\text { Espectrometry of plasma } \\
\text { emission in argon induced } \\
\text { plasma (ICP-AES) }\end{array}$ & Perkin -Elmer, model Optima 3000 \\
\hline $\mathrm{P}$ quantification & Colorimetry. Absorbance $(420 \lambda)$ & Model 600 S Espectrophotometer \\
\hline K quantification & Flame photometry & Model Digitime Digimed - DM 61 Flame photometer \\
\hline Total C & Total combustion & CHN -600 Analyser \\
\hline Total N & $\begin{array}{l}\text { Steam Distillation (Method } \\
\text { Kjeldahl, described by Bremner } \\
\text { \& Mulvaney, 1982) }\end{array}$ & $\begin{array}{l}\text { Fume chamber, digestor block, } \mathrm{H}_{2} \mathrm{SO}_{4} \\
\text { distillator, autotitrator, etc }\end{array}$ \\
\hline
\end{tabular}




\section{Statistical analysis}

In relation to the statistical analysis, the data of pseudo-total nutrient contents as well as of soil lost from the three gullies were checked for normality and homogeneity of the model residue variances, using SAEG 4.0 software. The data did not meet these requirements when transformed into $\log (\mathrm{X}+1)$. Therefore, variance analysis and Bonferroni's t test were performed using SISVAR software (Ferreira, 2003).

\section{RESULTS AND DISCUSSION}

The characteristics of these two gullies, although not statistically analyzed, were considerably different mainly in terms of the slope type, water collection area, average slope, volume, and depth (Table 2). For the characteristics of contribution area, width, length, slope length above the gully and soil thickness (A+B horizons), the gullies tended to be more similar. This problem of comparison does not exist only within a same study area. According to Poesen et al. (2003), there is a lack of norms for gully studies, so data obtained from different environments are not always suitable for comparisons.

In the gullies, deep cuts and a fairly thick $\mathrm{C}$ horizon were observed, reaching a depth of $15 \mathrm{~m}$ in the recovering gully (Table 2 ). The characteristic of high erodibility of the $\mathrm{C}$ horizon or gneiss-originated soil layer (Morais et al., 2004), together with the soil morphological and topographical characteristics (profile) observed in the studied areas indicate the probable causes for the occurrences of gullies with great area and volume in this region.

In relation to the soil types in the mid-third of the slopes in the studied areas, both the recovered and the recovering gullies were classified as Yellow-Red
Latosol and the gully without treatment as YellowRed Ultisol.

For the rainfall during the experiment period from July 2005 to June 2006, a total rainfall of $1,149 \mathrm{~mm}$ was registered, most concentrated between November 2005 and March 2006 (83\% of the total). February with $340 \mathrm{~mm}$ rain, was the most rainy month in this period. The physical characteristics and erosivity index $\mathrm{El}_{30}$ of the erosive and non- erosive rains are presented in table 3 .

The strongest rainfalls occurred in 2005, between November 25th and 29th, December 06th and December10th, in the first evaluation; December 24th, 2005, January 1th and January 4st 2006, in the second evaluation; January 27th and January 29th 2006 in the third evaluation; and February 23th for the fourth evaluation. This shows that during the period from November 25th 2005 until February 23th 2006, 25 rainfalls were considered erosive [precipitation above $10 \mathrm{~mm}$ or $6 \mathrm{~mm}$, lasting less than 15 minutes (Cabeda, 1976)].

The distribution of erosivity in the assessed period was highly concentrated (Table 3). Expressed in an accumulated value, erosivity was $4,559.8 \mathrm{MJ} \mathrm{mm}^{-1}$ $\mathrm{h}^{-1}$ year ${ }^{-1}$, a value that virtually represents the yearly erosivity of this region which, according to Montebeller et al. (2007), is around 4,000 to 6,000 $\mathrm{MJ} \mathrm{mm} \mathrm{ha}^{-1} \mathrm{~h}^{-1}$ year ${ }^{-1}$.

The soil loss from the gully without intervention was measured in four evaluations, and from the recovering and recovered gullies in three assessments (Figure 1). In the first three evaluations of the gully without intervention, 52.5, 20.5, and $29.0 \mathrm{Mg}$ of sediments were observed, and $1.0,1.7$, and $1.8 \mathrm{Mg}$ from the gully in recovery, indicating a reduction of losses of approximately 98, 92 and $94 \%$, respectively. From the recovered gully, the sediment production during this period was so low that quantification was

Table 2. Morphometric characteristics of slopes and gullies

\begin{tabular}{|c|c|c|}
\hline \multirow{2}{*}{ Attribute } & \multicolumn{2}{|c|}{ Gully } \\
\hline & Recovering & No intervention \\
\hline Contribution area for natural runoff (ha) & 0.78 & 1.55 \\
\hline Gully area $\left(\mathrm{m}^{2}\right)$ & 901 & 1,145 \\
\hline Greatest width (m) & 19.7 & 20.9 \\
\hline Least width $(\mathrm{m})$ & 0.7 & 1.8 \\
\hline Length of gully (m) & 74.9 & 90.7 \\
\hline Greatest depth (m) & 17 & 11 \\
\hline Least depth (m) & 5 & 1.2 \\
\hline Average depth (m) & 11 & 8 \\
\hline Volume $\left(\mathrm{m}^{3}\right)$ & 6,500 & 10,718 \\
\hline Length of slope above gully (m) & 80 & 96.9 \\
\hline Average thickness of solum (hor. A+B) (m) & 1.8 & 2.2 \\
\hline Average incline of collection area (\%) & 59 & 29 \\
\hline Shape of slope & Linear/Convex & Concave \\
\hline
\end{tabular}


Table 3. Characteristics of erosive and non- erosive rains in Pinheiral between 11/25/05 and 2/23/06, as found by means of Chuveros software

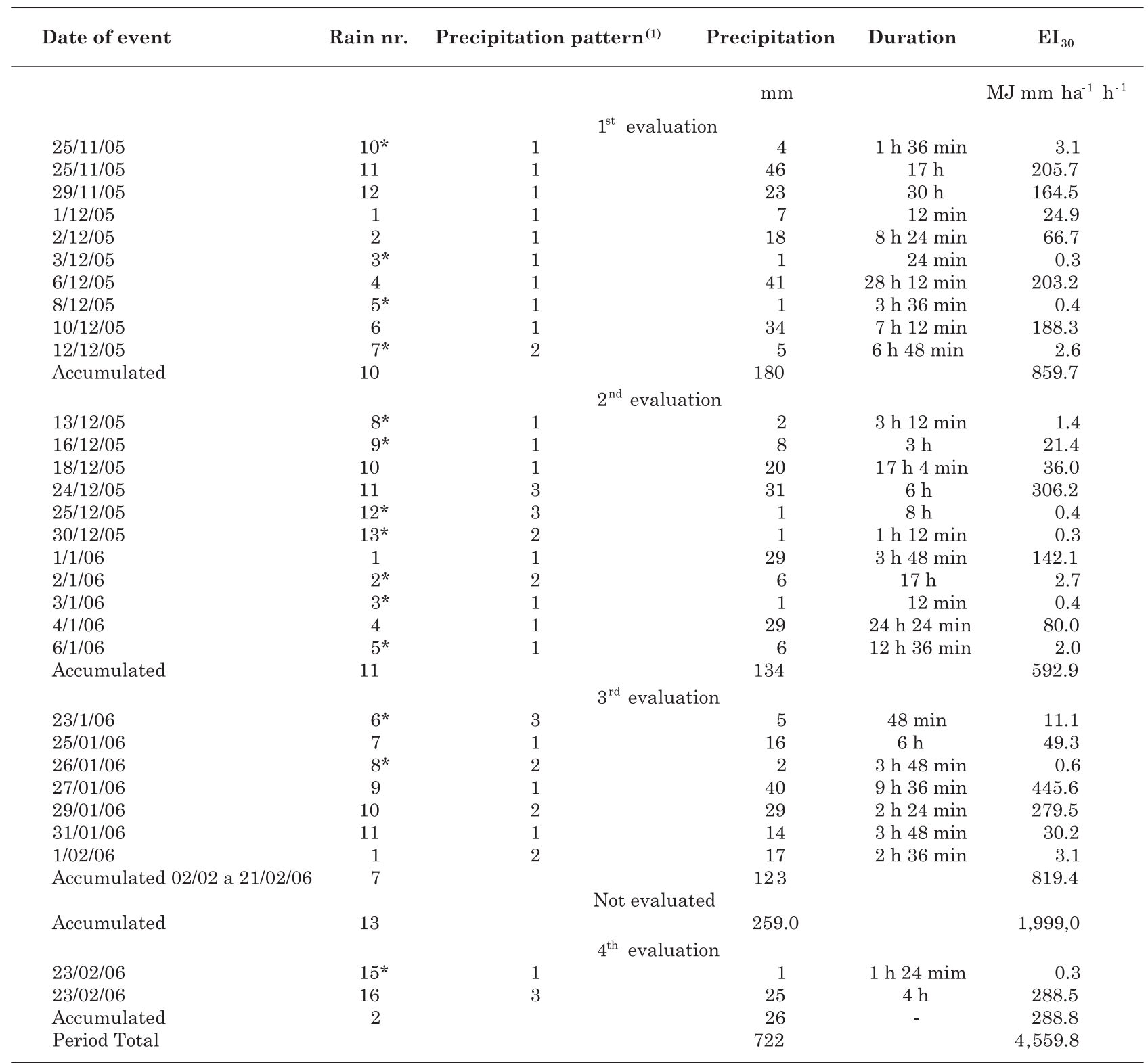

${ }^{(1)}$ Precipitation pattern: 1: advanced, 2: intermediate and 3: delayed. *: non-erosive rains (Cabeda, 1976).

not possible. Nevertheless, it is likely that a certain amount of sediments was produced there, not retained by the collector which might have limited retention of fine sediments only, those less able to be conveyed by the flow. Results from this comparison should be interpreted with caution, since the areas were not similar.

In the fourth evaluation of the gully without intervention, $93 \mathrm{Mg}$ of soil were quantified in one only erosive rain. This high soil loss was associated to the landslide of palisades that occurred within the gully before the rain.

This rain characteristics seem to have contributed also to this greater loss. The erosivity of this rain

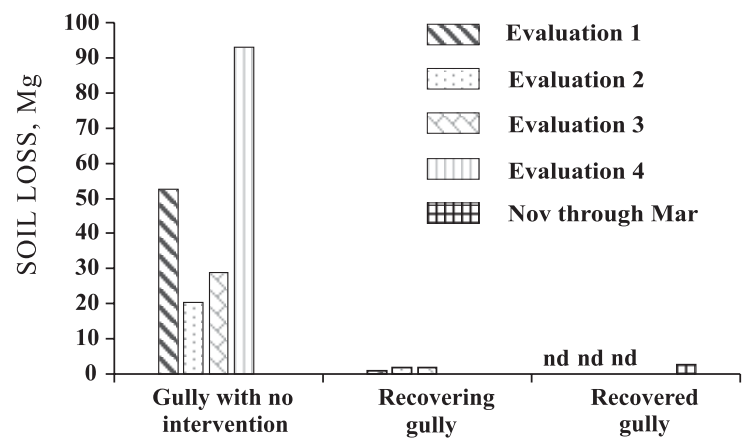

Figure 1. Soil loss at gullies at different stages of recovery from different evaluations. 
was $288.5 \mathrm{MJ} \mathrm{mm} \mathrm{ha}^{-1} \mathrm{~h}^{-1}$, while on the other hand, the precipitation pattern was classified as delayed (3), which, due to the prior humidity, results in greater surface runoff and, consequently, particles are dragged away. The lower accumulated $\mathrm{EI}_{30}$ (Table 3) indicating a greater soil loss in the fourth than in the other evaluations indicates the existence of other variables not considered by this index, which caused the landslide of the palisades within the gullies.

From the recovered gully, sediment production occurred only at the end of the rainy season, when 2.7 Mg of sediments were registered. By adding the obtained values in all evaluations, a soil loss of 195 , 4.5 and $2.7 \mathrm{Mg}$ was recorded from the gullies without intervention, the one under recovery and the recovered one, respectively. One should take into account that the evaluation period for soil loss corresponded to $40 \%$ only of the recorded total annual precipitation in the region under study.

The soil loss in sediments of the gullies under study in the first three evaluations was statistically analyzed (Figure 2). It can be seen that from the gully without intervention, the soil loss was greater than from the other gullies, which did not differ from each other. Based on these results, one could say that the physical interventions alone would be sufficient for an efficient soil loss reduction from gullies. Nevertheless, it is worth highlighting that not using biological practices may require permanent maintenance practices in the area, such as cleaning of terraces and infiltration basins, rebuilding of palisades, etc., which would increase the costs in the long run, without however achieving the final goal of minimizing human intervention and re-establishing the ecological functions in the area.

Montolar-Sparovek et al. (1999), when studying the soil loss from gullies in Piracicaba-SP, recorded

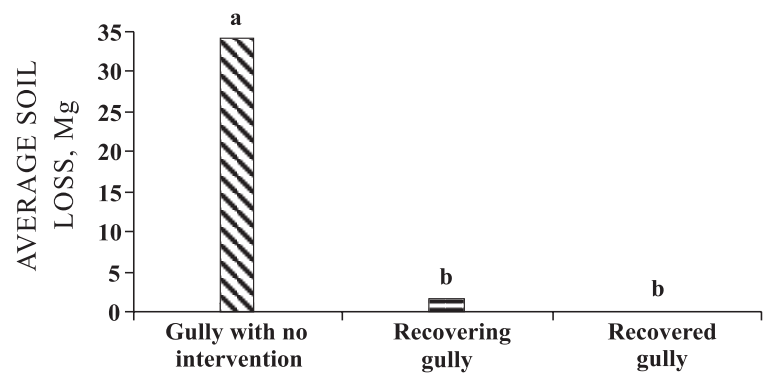

Figure 2. Average soil loss from gullies in different recovery stages. Averages of three replications (evaluations). Averages followed by the same letter did not differ from each other by Bonferroni's t-test (5\%)

an average amount of $12.7 \mathrm{Mg} \mathrm{ha}^{-1}$ year- $^{-1}$ from 16 gullies, including erosion rills in the surroundings.

Table 4 presents the results of the granulometric analysis of the evaluations performed in the three gullies. Of the gully without intervention, sediments were classified as heavy clay in the first three evaluations, and as sandy loam in the last two, therefore indicating clay removal by the torrent as the rains continued.

In the recovering gully, there was predominance of finer fractions such as clay and silt, wherein the first evaluation, those fractions added up to $90 \%$ of the total, being therefore classified as silt heavy clay. This result may be related to the lower flow of the torrent after building the physical barriers, and mainly to the filtering of sediments at the palisades through the raffia bags. As evaluations succeeded, though, these finer fractions decreased, similarly to the gully without intervention.

Table 4. Granulometry of sediments collected in evaluations of the studied gullies \pm standard error

\begin{tabular}{|c|c|c|c|c|c|c|}
\hline \multirow{2}{*}{ Evaluation } & \multicolumn{3}{|c|}{ Sand } & \multirow{2}{*}{ Silt } & \multirow{2}{*}{ Clay } & \multirow{2}{*}{ Textural Class } \\
\hline & Coarse & Fine & Total & & & \\
\hline & \multicolumn{5}{|c|}{$-\mathrm{g} \mathrm{kg}^{-1}$} & \\
\hline & \multicolumn{5}{|c|}{ Gully with no intervention* } & \\
\hline $1^{\text {st }}$ & $626 \pm 31$ & $118 \pm 13$ & $743 \pm 23$ & $79 \pm 12$ & $177 \pm 14$ & Heavy clay \\
\hline $2^{\text {st }}$ & $645 \pm 69$ & $152 \pm 16$ & $796 \pm 87$ & $63 \pm 9$ & $140 \pm 23$ & Heavy clay \\
\hline $3^{\text {st }}$ & $704 \pm 20$ & $132 \pm 10$ & $836 \pm 12$ & $37 \pm 4$ & $128 \pm 9$ & Sand loam \\
\hline $4^{\text {st }}$ & $715 \pm 14$ & $91 \pm 6$ & $806 \pm 10$ & $55 \pm 5$ & $139 \pm 8$ & Sand loam \\
\hline \multirow[t]{2}{*}{ Average } & $647 \pm 17$ & $131 \pm 8$ & $778 \pm 14$ & $66 \pm 7$ & $156 \pm 9$ & Heavy clay \\
\hline & \multicolumn{5}{|c|}{ Recovering gully } & \\
\hline $1^{\text {st }}$ & $30 \pm 15$ & $72 \pm 18$ & $102 \pm 29$ & $546 \pm 26$ & $352 \pm 8$ & Silt heavy clay \\
\hline $2^{\text {st }}$ & $187 \pm 62$ & $174 \pm 26$ & $362 \pm 66$ & $369 \pm 52$ & $270 \pm 17$ & Sand loam \\
\hline $3^{\text {st }}$ & $471 \pm 75$ & $172 \pm 21$ & $643 \pm 58$ & $179 \pm 48$ & $178 \pm 20$ & Heavy clay \\
\hline \multirow[t]{2}{*}{ Average } & $260 \pm 56$ & $155 \pm 17$ & $415 \pm 60$ & $333 \pm 44$ & $252 \pm 18$ & Sand loam \\
\hline & \multicolumn{5}{|c|}{ Recovered gully } & \\
\hline Nov. through at Mar. & $521 \pm 42$ & $238 \pm 24$ & $759 \pm 59$ & $177 \pm 46$ & $64 \pm 13$ & Heavy clay \\
\hline
\end{tabular}


At the recovered gully, sediments had a sandy loam granulometry. This more coarse texture is probably related to the decreased efficiency of the palisades in filtering the sediments, since they were not reformed after the area was overgrown by the leguminous trees, and after the observation of a small production of sediments deposited in the collector.

Table 5 presents the pseudo-total nutrient contents to a depth of $30 \mathrm{~cm}$ in the surrounding areas, as well as within the recovered gully and the gully without intervention and in the sediments from both. K contents in the sediments were significantly greater than in the surrounding area and within the gully without intervention.

There were no significant differences between the mean contents of $\mathrm{P}$ and $\mathrm{C}$, although the contents tended to be higher in the surrounding areas. This absence of significant difference can be due to the high values of variation coefficient (VC) in the data.

For N, the content in the surrounding area of the recovered gully was higher than in the other areas in the $0-10 \mathrm{~cm}$ layer, making a contribution of the implanted legumes to nitrogen fixation evident.

The values of the $\mathrm{C} / \mathrm{N}$ ratio in this gully, within the gullies were near 10:1, indicating the importance of nitrogen for the enrichment of soil carbon (Sisti et al., 2004).

In the surrounding area, the $\mathrm{C} / \mathrm{N}$ ratio in the 10 20 and $20-30 \mathrm{~cm}$ layers was taken as atypical, and can be related to the presence of charcoal from a previous fire in the area.

In the gully without intervention, significant differences among the contents were only found for $\mathrm{K}$ in the sediments and other sampled areas, showing $\mathrm{K}$ enrichment in the sediments of this gully. When comparing $\mathrm{K}$ contents of the two gullies, a trend for a greater content in the recovered gully is noted. This can be explained by the higher presence of mica observed in the samples from the latter. According to Unamba-Oparah (1985), cited by Melo et al. (2004), the greater $\mathrm{K}$ amount in the sediments from the $\mathrm{C}$ horizon may be related to the yet unweathered minerals. For P, sediments tended to have lower contents than in the surrounding areas and within the recovered gully.

In relation to the total loss, the elements $\mathrm{K}$ and $\mathrm{Mg}$ were the nutrients lost in greatest amount in all evaluations since they were found at highest concentrations in the sediments (Table 6). In the gully without intervention, it can be observed that, in the

Table 5. Pseudo-total and total contents of nutrients in the surroundings (mid-third), interior and sediments of the recovered gully and the gully without intervention

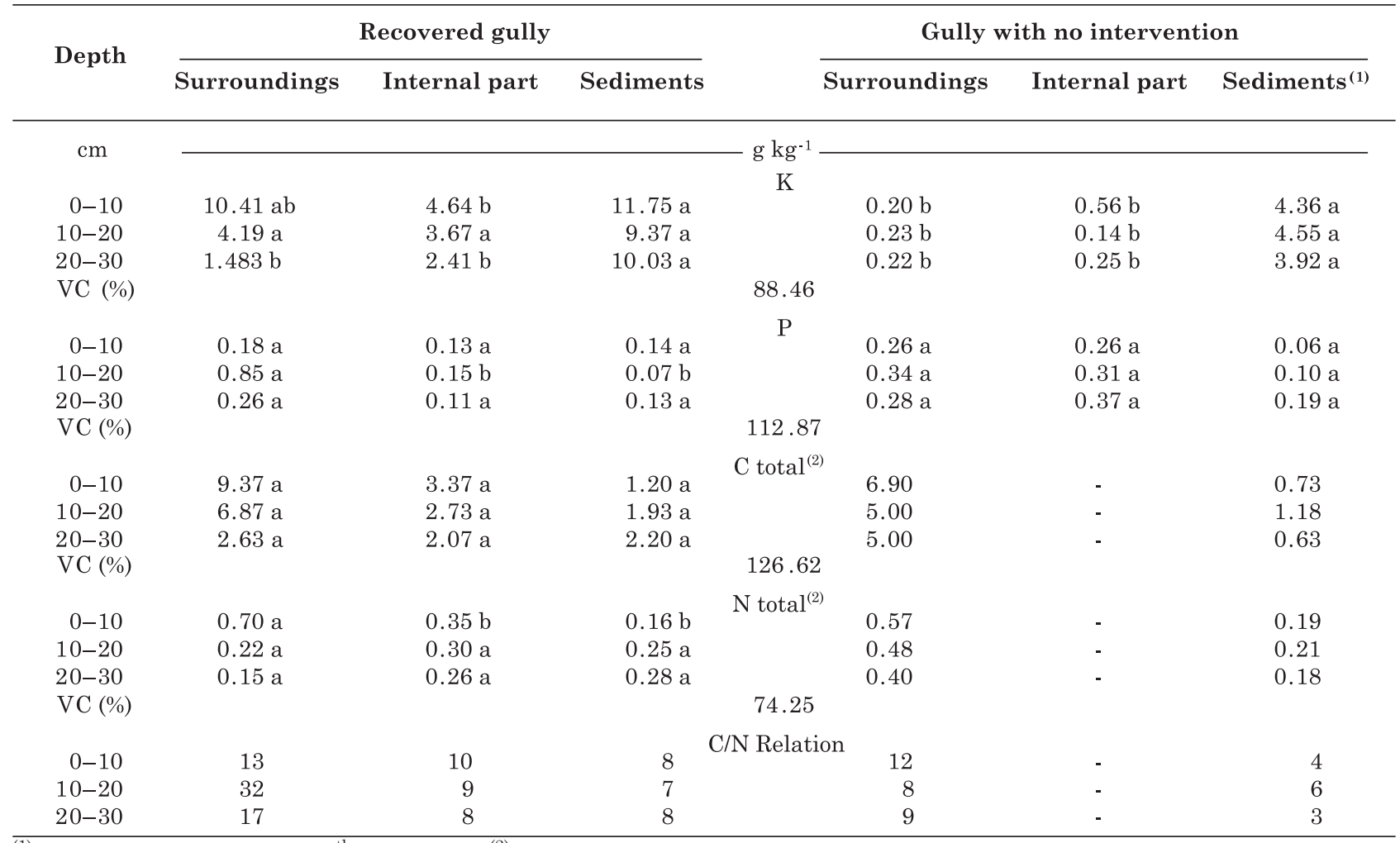

${ }^{(1)}$ Averages referring to the $4^{\text {th }}$ evaluation. ${ }^{(2)} \mathrm{C}$ and $\mathrm{N}$ total values for the surrounding area of the gully without intervention were taken from the recovering gully as reference (averages of 4 replications). Averages followed by the same letter in a row for each depth and gully did not differ from each other by Bonferroni's t-test (5\%). 
Table 6. Total loss of pseudo-total and total nutrients from the three gullies under study in the summer 2005/ 2006

\begin{tabular}{|c|c|c|c|c|c|c|}
\hline Evaluation & $\mathbf{C a}$ & Mg & $\mathbf{K}$ & $\mathbf{P}$ & C total & $\mathrm{N}$ total \\
\hline & \multicolumn{6}{|c|}{ Gully with no intervention } \\
\hline $1^{\mathrm{a}}$ & 3.4 & 236.7 & 261.4 & 6.2 & 7.1 & 1.3 \\
\hline $2^{\mathrm{a}}$ & 1.3 & 86.4 & 97.3 & 2.3 & 2.5 & 0.5 \\
\hline $3^{a}$ & 3.2 & 131.5 & 152.8 & 3.8 & 2.7 & 0.5 \\
\hline $4^{\mathrm{a}}$ & 10.7 & 368.7 & 432.7 & 9.2 & 6.1 & 1.4 \\
\hline \multirow[t]{2}{*}{ Total } & 18.7 & 823.3 & 944.2 & 21.4 & 18.4 & 3.7 \\
\hline & \multicolumn{6}{|c|}{ Recovering gully } \\
\hline $1^{\mathrm{a}}$ & 0.32 & 4.32 & 6.30 & 0.13 & 0.41 & 0.04 \\
\hline $2^{\mathrm{a}}$ & 0.35 & 10.60 & 11.01 & 0.47 & 0.44 & 0.05 \\
\hline $3^{a}$ & 0.17 & 11.76 & 13.22 & 0.34 & 0.22 & 0.03 \\
\hline \multirow[t]{2}{*}{ Total } & 0.84 & 26.68 & 30.53 & 0.93 & 1.07 & 0.12 \\
\hline & \multicolumn{6}{|c|}{ Recovered gully } \\
\hline Nov th rough at Mar. & 1.3 & 35.1 & 29.4 & 0.30 & 0.45 & 0.06 \\
\hline
\end{tabular}

total lost soil of $195 \mathrm{Mg}$ during the evaluation period, altogether nearly $1.77 \mathrm{Mg}$ of those nutrients were carried away. This higher $\mathrm{Ca}$ and $\mathrm{Mg}$ loss can be associated to a greater abundance of the elements at the location, associated to the material of origin.

Not taking into consideration the heterogeneity of the environments, actions for erosion control by means of physical and biological practices reduced nutrient losses by more than $96 \%$ when compared to a gully without intervention.

\section{CONCLUSIONS}

1. The erosivity index $\mathrm{EI}_{30}$ and/or total rain volume did not explain the amount of sediments removed from the gullies studied; other factors should therefore be investigated.

2. The use of narrow-base terraces, together with infiltration basins at the edges of the water collection area, as well as palisades and bamboo both within and in the surroundings of the gully (physical practices), did not obtain different results than the use of physical practices plus the planting of leguminous trees inoculated by microorganisms (biological practices) in the water collection area. However, the use of biological practices should be considered in order to reduce future costs for the maintenance of physical practices as well as for the reestablishment of the ecological functions in the area.

3. The use of physical practices associated to replanting with nodulated leguminous trees inoculated by microorganisms reduced the soil loss in the gullies by $99 \%$, and nutrient loss by $96 \%$ under the experimental conditions, highlighting the efficiency of the technique.

\section{AKNOWLEDGEMENTS}

The authors thank the technicians Fernando Cunha and Telmo Felix da Silva, scholarship holders and trainees at the Embrapa Agrobiology Leguminous Laboratory; the Soil Department of UFRRJ; Embrapa Soils; the Agriculture College Nilo Peçanha/UFF, and the National Council of Scientific and Technological Development $(\mathrm{CNPq})$, as well as the Research Foundation of the State of Rio de Janeiro (FAPERJ), for the master scholarship of the first author.

\section{LITERATURE CITED}

AB'SABER, A.N. Províncias geológicas e domínios morfoclimáticos no Brasil. Geomorfologia, 20:1-26, 1970.

BERTOL, I.; LEITE, D.; GUADAGNIN, J.C. \& RITTER, S.R. Erosão hídrica em um Nitossolo Háplico submetido a diferentes sistemas de manejo sob chuva simulada: II. Perdas de nutrientes e carbono orgânico. R. Bras. Ci. Solo, 28:1045-1054, 2004.

BREMNER, J.M. \& MULVANEY, C.S. Nitrogen total. In: PAGE, A.L.; MILLER, R.A. \& KEENEY, D.R., eds. Methods of soil analysis. 2.ed. Madison, American Society of Agronomy, 1982. p.595-624.

CABEDA, M.S.V. Computation of storm EI value. West Lafayette, Purdue University, 1976. 6p.

COMITÊ PARA INTEGRAÇÃO DA BACIA HIDROGRÁFICA DO RIO PARAÍBA DO SUL - CEIVAP. Diagnóstico da situação atual dos recursos hídricos. Rio de Janeiro, Fundação Coppetec/UFRJ/ANA, 2002.

COGO, C.M.; ELTZ, F.L.F.; CASSOL, A. \& SANTOS, M.V. Erosividade das chuvas de Uruguaiana-RS, determinada pelo índice $\mathrm{EI}_{30}$, no período de 1963-1990. In: CONGRESSO BRASILEIRO DE CIÊNCIA DO SOLO, 29., Ribeirão Preto, 2003. Anais. Ribeirão Preto, Sociedade Brasileira de Ciência do Solo, 2003. CD-ROM. 
DAY, P.R. Particle fractionation and particle size analysis. In: BLACK, C.A., ed.. Methods soil analysis. Madison, American Society of Agronomy, 1965. p.545-567.

DIAS, J.E. Análise ambiental por geoprocessamento do município de Volta Redonda. Seropédica, Universidade Federal Rural Rio de Janeiro, 1999. 180p. (Tese de Mestrado)

DIAS, J.E.; GOMES, O.V.O. \& GOES, M.H.B. Áreas de riscos de erosão do solo: Uma aplicação por geoprocessamento. Flor. Amb., 8:1-10, 2001.

EMPRESA BRASILEIRA DE PESQUISA AGROPECUÁRIA . EMBRAPA. Centro Nacional de Pesquisa de Solos. Sistema brasileiro de classificação de solos. 2.ed. Rio de Janeiro, SCNPIS, 2006. 306p.

EMPRESA BRASILEIRA DE PESQUISA AGROPECUÁRIA . EMBRAPA. Centro Nacional de Pesquisa de Solos. Manual de Métodos de Análise de Solo. 2.ed. Rio de Janeiro, 1997. $212 \mathrm{p}$.

FADIGAS, F.; AMARAL SOBRINHO, N.M.B.; MAZUR, N.; ANJOS, L.H.C. \& FREIXO, A.A. Concentrações naturais de metais pesados de metais pesados em algumas classes de solos brasileiros. Bragantia, 61:151-159, 2002.

FERREIRA, D.F. Sistema para análise de variância para dados balanceados (Sisvar). Lavras, Universidade Federal de Lavras, 2003. Versão 4.3 .

FOSTER, G.R. Understanding ephemeral gully erosion. Soil conservation. Washington, National Academy of Science Press, 1986. v.2. p.90-125.

GUERRA, A.J.T. Processos erosivos nas encostas. In GUERRA, A.J.T. \& CUNHA, S.B., orgs. Geomorfologia: Uma atualização de bases e conceitos. Rio de Janeiro, Bertrand Brasil, 2003. p.149-199.

MACEDO, J.R.; CAPECHE C.L.; MELO, A.S.; MENEGUELLI, N.A. \& FRANCO, A.A. Revegetação da área de contribuição e estabilização de voçorocas através de práticas mecânicas e vegetativas. Rio de Janeiro, Embrapa Solos, 1998. p.1-6. (Pesquisa em Andamento)

McGRATH, S.P. \& CUNLIFFE, C.H. A simplified method for the extration of metals $\mathrm{Fe}, \mathrm{Zn}, \mathrm{Cu}, \mathrm{Ni}, \mathrm{Cd}, \mathrm{Pb}, \mathrm{Cr}$, Co and Mn from soils and sewage sludges. J. Sci. Food Agric., 36:794-798, 1985.

MELO, V.F.; RIBEIRO, A.N.; MASCHIO, P.A.; CORRÊA, G.F. \& LIMA, V.C. Mineralogia e formas de potássio e magnésio em diferentes classes de pesos e tamanhos da fração areia de solos do Triângulo Mineiro. R. Bras. Ci. Solo, 28:219. 231, 2004.

MENEZES, C.E.G.; ANJOS, L.H.C.; PEREIRA, M.G.; SOUZA, J.M.P.F. \& TOLEDO, L.O. Influência da topografia e cobertura vegetal em propriedades edáficas no ambiente de mar de morros, Pinheiral, RJ. Agronomia, 34:70-77, 2000.
MONTEBELlER, C.A.; CEDDIA, M.B.; CARVALHO, D.F.; VIEIRA, S.R. \& FRANCO, E.M. Variabilidade espacial do potencial erosivo das chuvas no Estado do Rio de Janeiro. Eng. Agríc., 27:426-435, 2007.

MONTOLAR-SPAROVEK, R.B.; VIDAL-TORRADO, P. \& SPAROVEK, G. Erosão em sulcos, entressulcos e voçorocas em uma microbacia de Piracicaba (SP) intensivamente cultivada. Sci. Agric., 56:859-865, 1999.

MORAIS, F.; BACELLAR, L.A.P. \& SOBREIRA, F.G. Análise da erodibilidade de saprolitos de gnaisse. R. Bras. Ci. Solo, 28:1055-1062, 2004.

OLIVEIRA, J.A. Caracterização física do Ribeirão Caximbal Pinheiral-RJ, e suas principais paisagens degradadas. Seropédica, Universidade Federal Rural do Rio de Janeiro, 1998. 143p. (Tese de Mestrado)

POESEM, J.; NACHTERGAELE, J.; VERSTRAETEN, G. \& VALENTIN, C. Gully erosion and environmental change: Importance and research needs. Catena, 50:91-133, 2003.

SANTOS, A.C.; SALCEDO, I.H. \& CANDEIAS, A.L.B. Relação entre o relevo e as classes texturais do solo na microbacia de Vaca Brava (PB). R. Bras. Cartogr., 54:86-94, 2002.

SANTOS, R.D.; LEMOS, R.C.; SANTOS, H.G.; KER, J.C. \& ANJOS, L.H.C. Manual de descrição e coleta de solo no campo. 5.ed. Viçosa, MG, Folha de Viçosa, 2005. 100p.

SISTI, C.P.J.; SANTOS, H.P.; KOCHHANN, R.A.; ALVES, B.J.R.; URQUIAGA, S. \& BODDEY, R.M. Change in carbon and nitrogen stocks in soil under 13 years of conventional or zero tillage in southern Brazil. Soil Tillage Res., 76:39-58, 2004.

SOIL CONSERVATION SERVICE. Department of Agriculture Farmers. How to control a gully. Bulletin, 2171:1-16, 1973.

UNAMBA-OPARAH, I. The potassium status of the sandy soils of Northern Imo State, Nigeria. Soil Sci., 139:437445,1985 .

UNIVERSIDADE PÚBLICA DE NAVARRA - UPNA. IV INTERNATIONAL SYMPOSIUM ON GULLY EROSION, 4., 2009. Disponível em: <http:// www.unavarra.es/erosion/principal.html> Acesso em:16 de fevereiro 2009.

VALENTIN, C.; POESEM, J. \& YOUNF LI. Gully erosion: Impacts, factors and control. Catena, 63:132-153, 2005.

VANDEKERCKHOVE, L.; POESEN, J.; WIJDENES, D.O.; GYSSELS, G.; BEUSELINCK, L. \& LUNA, E. Characteristics and controlling factors of bank gullies in two semi-arid Mediterranean environments. Geomorphology, 33:37-58, 2000 